\title{
MICROSURGICAL MANAGEMENT OF A RARE INCIDENTAL INTRAVENTRICULAR MENINGIOMA: A CASE REPORT AND RELEVANT LITERATURE REVIEW
}

\author{
Marina Raguž ${ }^{1}$,Ante Rotim², Tomislav Sajko ${ }^{2,3}$, Mia Jurilj2, $^{2}$ \\ Bruno Splavski ${ }^{2,3,4,5}$ and Krešimir Rotim ${ }^{2,3,4}$ \\ ${ }^{1}$ Department of Neurosurgery, Dubrava University Hospital, Zagreb, Croatia; \\ ${ }^{2}$ Department of Neurosurgery, Sestre milosrdnice University Hospital Centre, Zagreb, Croatia; \\ ${ }^{3}$ University of Applied Health Sciences, Zagreb, Croatia; \\ 4Josip Juraj Strossmayer University of Osijek, Faculty of Medicine, Osijek, Croatia; \\ ${ }^{5}$ Josip Juraj Strossmayer University of Osijek, Faculty of Dental Medicine and Health, Osijek, Croatia
}

\begin{abstract}
SUMMARY - Intraventricular meningiomas are rare and make up between $0.5 \%$ and $3 \%$ of all intracranial meningiomas, representing one of the most challenging tumors in neurosurgery due to their difficult location. Being initially asymptomatic, such tumors usually attain large size before clinical presentation and diagnostic detection. Available literature concerned with their surgical management remains scarce. Herein, we present a case of microsurgical resection of incidental intraventricular meningioma in a 32-year-old female patient who was admitted to the hospital due to the sudden loss of consciousness, retrograde amnesia, and nausea following a head trauma. Routine brain magnetic resonance imaging revealed an irregular expansive formation located in the occipital horn of the right lateral ventricle showing heterogeneous contrast enhancement. The patient underwent right-side temporal osteoplastic craniotomy with total tumor microsurgical resection followed by external ventricular drainage, and recovered fully afterwards. Histopathologic analysis of tumor tissue samples confirmed the tumor as meningioma WHO grade I. Postoperative brain computed tomography confirmed complete tumor resection. In conclusion, intraventricular meningiomas are rather rare extraaxial tumors and may present with various symptoms depending on their size and difficult location. The development of most modern neuroimaging methods offers the opportunity of their precise and accurate diagnosis, better surgical planning, and favorable outcome. Microsurgical gross resection utilizing intraoperative neuromonitoring and cutting-edge neurosurgical armamentarium remains the treatment of choice for these location-challenging and surgically demanding, predominantly benign intracranial tumors.
\end{abstract}

Key words: Meningioma, intraventricular, incidental; Microsurgical management

\section{Introduction}

Meningiomas are mostly benign intracranial tumors arising from the arachnoid cap cells, and the second most common primary tumors of the central neu-

Correspondence to: Bruno Splavski, $M D, P h D$, Department of Neurosurgery, Sestre milosrdnice University Hospital Centre, Vinogradska c. 29, HR-10000 Zagreb, Croatia

E-mail: splavuno@gmail.com

Received January 12, 2021, accepted February 23, 2021 ral system in adults. They may be found in any intracranial location including brain convexity, and the skull base $e^{1-5}$. Still, intraventricular meningiomas (IVMs) are rare lesions with an incidence of approximately $0.5 \%-3 \%$ of all intracranial meningiomas ${ }^{6-13}$. As with other meningiomas, a female predominance was observed in previous research, while most of IVMs were diagnosed after the third decade of life, and were less common in pediatric patients ${ }^{6,14-17}$. They are mostly observed in lateral ventricles, especially the left one, 


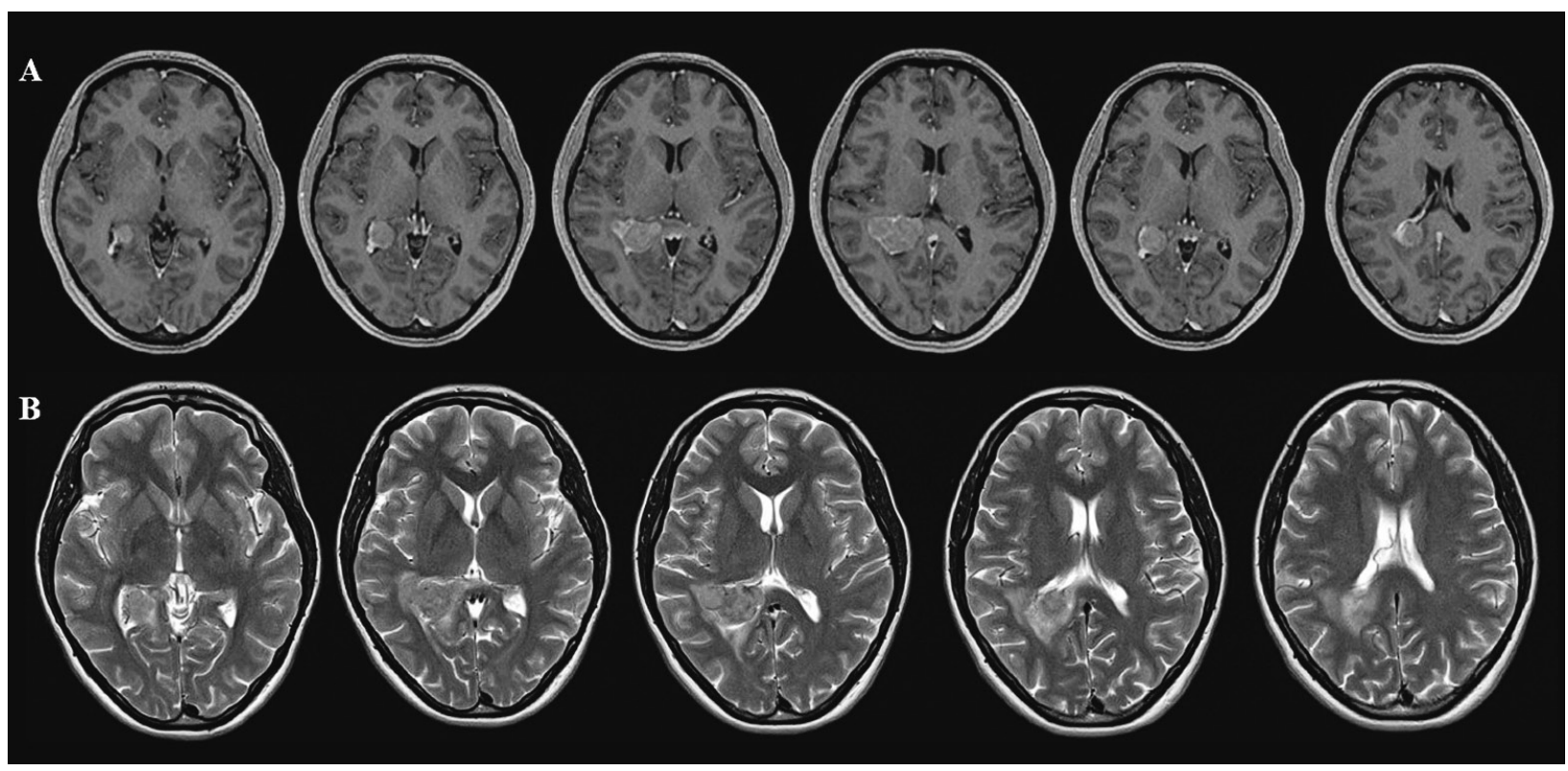

Fig. 1. Initial magnetic resonance imaging (MRI) of the brain showing an irregular expansive mass located in the occipital horn of the right lateral ventricle. A series of axial T1-weighted MRI scans showing heterogeneous contrast enhancement of the tumor mass (A); axial T2-weighted MRI showing perifocal edema spreading through the splenium of corpus callosum, as well as mild asymmetry of ventricular system with discrete dilatation of the right lateral ventricle (B).

with trigone region being the most common location in more than $90 \%$ of cases ${ }^{8,12,14,18-21}$.

Clinical manifestations of IVMs depend primarily on tumor location and size, since small tumors mostly have no notable neurological symptoms. Therefore, they can easily grow to a considerable size before becoming symptomatic, due to a relatively large compensating space of the ventricular system, especially in lateral ventricles. Still, as they enlarge in size, several symptoms including the rise of intracranial pressure (ICP), visual field defects, ataxia, and motor weakness may appear ${ }^{7,10-12,14,18,22}$. Progressive cognitive problems and memory loss, and/or rare intraventricular hemorrhage may also be presenting signs ${ }^{9,23,24}$. Many symptoms may be transient, which greatly contributes to delayed diagnosis in a number of patients ${ }^{6}$.

Advances in modern neuroimaging techniques, especially better availability of computed tomography (CT) and magnetic resonance imaging (MRI), have increasingly led to the identification of patients with incidental/asymptomatic meningiomas such as IVMs ${ }^{2}$. Additionally, modern neuroimaging techniques including navigation offer the opportunity for a more precise diagnosis and better surgical planning when such complex tumors in difficult locations are concerned. Microsurgical gross tumor resection utilizing intraoperative neuromonitoring and cutting-edge neurosurgical armamentarium remains the best treatment option for these rare, location-challenging and surgically demanding lesions.

Herein, we present a case of incidental IVM detected after routine screening following violent head trauma in a young female patient, discussing contemporary microsurgical technique and reviewing relevant literature.

\section{Case Report}

A 32-year-old female patient was presented with loss of consciousness, retrograde amnesia, and nausea due to violent head trauma. Apart from slightly impaired cognition, there were no other symptoms or neurological deficits at the time of admission. Initial $\mathrm{CT}$ and MRI brain scans revealed an irregular expansive formation located in the occipital horn of the right lateral ventricle measuring $2.2 \times 3.4 \times 2.5 \mathrm{~cm}$ in diameter. Perifocal edema spreading throughout the splenium of corpus callosum was observed, as well as mild asym- 


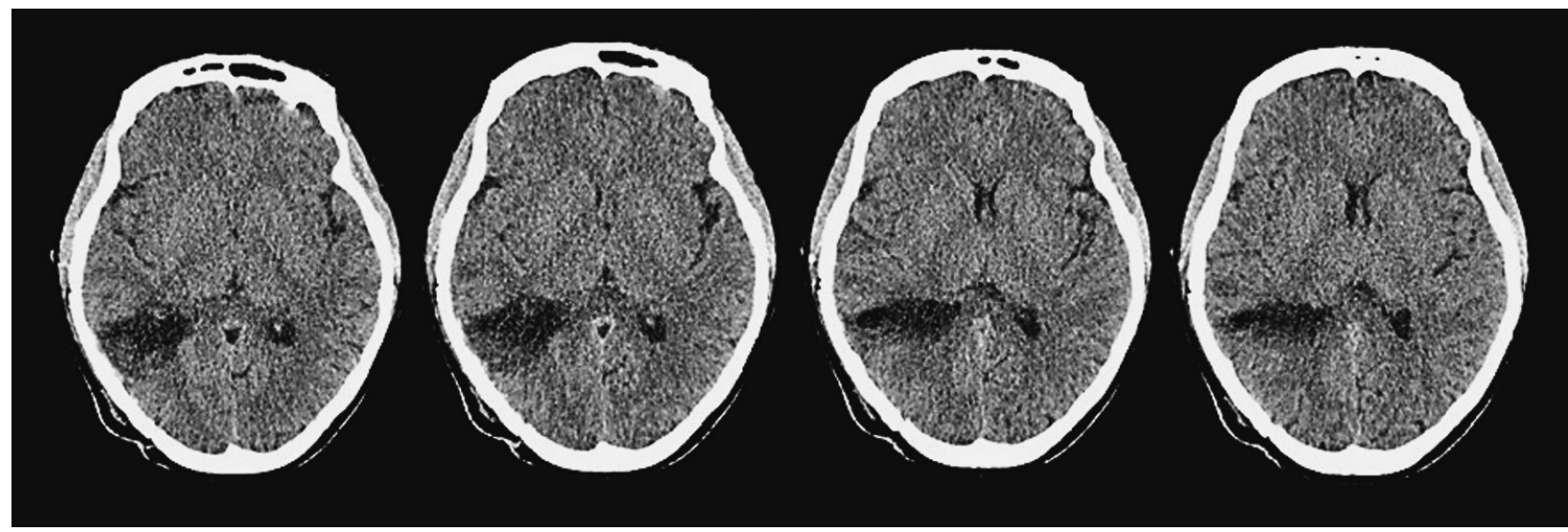

Fig. 2. Postoperative brain computed axial tomography revealing complete tumor resection without any signs of cerebral regional ischemia, hemorrhage, or residual tumor.

metry of the ventricular system with discrete dilatation of the right lateral ventricle. After the administration of intravenous contrast, the intraventricular mass showed heterogeneous enhancement (Fig. 1), resembling meningioma, or choroid plexus papilloma on differential diagnosis.

The patient underwent right-sided temporal osteoplastic craniotomy using the posterior middle temporal approach and opening of the right lateral ventricle, followed by total tumor removal with the help of neuronavigation, intraoperative neuromonitoring, and ultrasonic aspirator. In addition, external ventricular drainage was implanted at the end of the procedure. The immediate postoperative course was uneventful.

Brain CT scan performed on postoperative day 1 confirmed gross total tumor resection, without any signs of regional ischemia, intraventricular hemorrhage, and/or residual tumor (Fig. 2). The patient recovered fully having no neurological deficit or any postoperative complications. Tumor tissue samples acquired during the surgery were sent for histopathologic analysis. According to the current WHO classification $^{25}$, the samples corresponded to meningioma grade I. Hence, there was no need for adjuvant oncologic treatment.

\section{Discussion}

The ventricular system in general, and the lateral ventricles in particular, are rare locations of intracranial meningioma. Ever since the first case of such a tumor presented, several cases and case series have been briefly described in the literature ${ }^{26}$. Since such tumors arise from the arachnoid cap cells within the choroid plexus, they are relatively more common in the lateral in comparison to the third or fourth ventricles ${ }^{27}$. Hence, the majority of them originate from the trigone area, while the left lateral ventricle is more commonly described as a predominant $\operatorname{site}^{1,6,7,28}$. Nonetheless, our patient's tumor was located in the occipital horn of the right lateral ventricle, which made it even scarcer.

Clinical presentation depends on tumor location and size. Therefore, IVM usually remains asymptomatic prior to generating disruption of the cerebrospinal fluid pathways causing obstructive hydrocephalus. A wide variety of symptoms may be present, including raised ICP, visual field deficit caused by oppressed optic radiation or papilledema, and/or focal neurological deficits with contralateral motor/sensory loss due to compressive mass effect ${ }^{6,7,10-12,14,18,22-24}$.

In contemporary diagnostics, contrast enhancement on CT/MRI scans is helpful in delineating the characteristic regular lobular shape of a tumor causing dilatation of the affected ventricle ${ }^{6,9,11,20}$. Histologically, IVMs are described as predominantly fibrous, fibroblastic, and psammomatous, with fibroblastic meningioma as the most common type identified in the lateral ventricles ${ }^{9,11,27}$.

Intraventricular meningiomas are generally benign, and total tumor surgical excision remains the primary goal of management, despite difficulties related to its location and size $5,6,9,12,16$. Therefore, neurosurgical planning should be meticulous and accurate ${ }^{6}$. Various sur- 
gical approaches have been described for the IVMs located at the lateral ventricle trigone area, including temporo-parietal, posterior temporo-parietal, superior parietal, posterior middle temporal, posterior interhemispheric, transcallosal, and posterior parieto-occipital approach ${ }^{6,9,20,23,29}$, but the optimal one still remains controversial. Different factors such as patient preoperative symptoms, physical condition and $\mathrm{co}^{-}$ morbidity, minimization of transcortical injury, and better access to feeding blood vessels have to be taken into consideration when deciding on the best surgical approach. Superior parietal approach is often used providing direct tumor exposure throughout the intraparietal sulcus, thus evading interruption of optic radiation. Alternatively, the anterior transcallosal approach is well-suited for tumors that are located at the frontal horn, body of the lateral and the third ventricle, while the posterior transcallosal one is compatible for tumors in the trigone area. For tumors in the lateral ventricle temporal horn or inferior aspect of the trigone, the posterior middle temporal approach provides the shortest trajectory and the earliest access to choroidal vessels, enabling an advanced control of tumor blood supply. Consequently, we opted for this particular approach in our patient.

When deciding on the appropriate surgical approach, several important facts need to be emphasized including tumor size, its exact location, and its blood supply. Additionally, external ventricular drainage is highly recommended for the control of possible postoperative intraventricular hemorrhage $e^{6,9}$.

Although genuinely benign, IVMs can be exceptionally malignant, and can occasionally recur with the incidence of $0 \%-28 \% \%^{6,10,15,30}$. Thus, when subtotal tumor resection is performed, patients should be carefully monitored through follow ups ${ }^{6}$.

In conclusion, gross total microsurgical resection remains the treatment of choice for IVMs, bringing a highly satisfactory outcome if proper preoperative planning and meticulous intraoperative techniques are applied. However, the optimal surgical approach should be personalized and chosen according to the individual patient needs.

\section{References}

1. Erman T, Göcer AI, Erdogan E, Boyar B, Hacyakupoglu S, Zorludemir S. Intraventricular meningiomas: a review and re- port of eight cases. Neurosurg Q. 2004;14(3):154-60. doi: 10.1097/01.wnq.0000135754.99662.78.

2. Jadid KD, Feychting M, Höijer J, Hylin S, Kihlström L, Mathiesen T. Long-term follow-up of incidentally discovered meningiomas. Acta Neurochir (Wien). 2015;157(2):225-30. doi: 10.1007/s00701-014-2306-3.

3. Kleihues P, Cavenee WK. International Agency for Research on Cancer Pathology and Genetics of Tumours of the Nervous System. Lyon: IARC Press; 2000.

4. Lapras C, Deruty R, Bret P. Tumors of the lateral ventricles. Adv Tech Stand Neurosurg. 1984;11:103-67. doi: 10.1007/9783-7091-7015-1_5.

5. Splavski B, Hadzic E, Bagic I, Vrtaric V, Splavski B Jr. Simple tumor localization scale for estimating management outcome of intracranial meningioma. World Neurosurg. 2017;104:87682. doi: 10.1016/j.wneu.2017.05.039.

6. Chen C, Lv L, Hu Y, Yin S, Zhou P, Jiang S. Clinical features, surgical management, and long-term prognosis of intraventricular meningiomas: a large series of 89 patients at a single institution. Medicine (Baltimore). 2019;98(16):e15334. doi: 10.1097/MD.0000000000015334.

7. Criscuolo GR, Symon L. Intraventricular meningioma. A review of 10 cases of the National Hospital, Queen's Square (1974-1985) with reference to the literature. Acta Neurochir (Wien). 1986;83(3-4):83-91. doi: 10.1007/BF01402383.

8. Delfini R, Acqui M, Oppido PA, Capone R, Santoro A, Ferrante L. Tumors of the lateral ventricles. Neurosurg Rev. 1991;14:127-33. doi: 10.1007/BF00313037.

9. Ennhaili ZA, Chellaoui A, Ibahiouine K, Naja A, Lakhdar A, Elazhari A. Intraventricular meningiomas, a rare location for a common tumor: about 2 cases. Int J Radiol Radiat Ther. 2017; 4(4):408-10. doi: 10.15406/ijrrt.2017.04.00105.

10. Grujicic D, Cavallo LM, Somma T, llic R, Milicevic M, Raicevic S, et al. Intraventricular meningiomas: a series of 42 patients at a single institution and literature review. World Neurosurg. 2017;97:178-88. doi: 10.1016/j.wneu.2016.09.068.

11. Kim EY, Kim ST, Kim HJ, Jeon P, Kim KH, Byun HS. Intraventricular meningiomas: radiological findings and clinical features in 12 patients. Clin Imaging. 2009;33:175-80. doi: 10.1016/j.clinimag.2008.09.005.

12. Lyngdoh BT, Giri PJ, Behari S, Banerji D, Chhabra DK, Jainet VK. Intraventricular meningiomas: a surgical challenge. J Clin Neurosci. 2007;14:442-8. doi: 10.1016/j.jocn.2006.01.005.

13. Nakamura M, Roser F, Bundschuh O, Vorkapic P, Samii M. Intraventricular meningiomas: a review of 16 cases with reference to the literature. Surg Neurol. 2003;59:491-503. doi: 10.1016/s0090-3019(03)00082-x.

14. Bhatoe HS, Singh P, Dutta V. Intraventricular meningiomas: a clinicopathological study and review. Neurosurg Focus. 2006;20(3):E9. doi: 10.3171/foc.2006.20.3.10.

15. Liu M, Wei Y, Liu Y, Zhu S, Li X. Intraventricular meningiomas: a report of 25 cases. Neurosurg Rev. 2006;29:36-40. doi: 10.1007/s10143-005-0418-1. 
16. Nayar VV, DeMonte F, Yoshor D, Blacklock JB, Sawaya R. Surgical approaches to meningiomas of the lateral ventricles. Clin Neurol Neurosurg. 2010;112:400-5. doi: 10.1016/j.clineuro.2010.02.005.

17. Wang Y, Lin Z, Li Z, Zhao M, Hu M, Zhang H, et al. The incidence and risk factors of postoperative entrapped temporal horn in trigone meningiomas. World Neurosurg. 2016;90: 511-7. doi: 10.1016/j.wneu.2016.03.040.

18. Bertalanffy A, Roessler K, Koperek O, Gelpi E, Prayer D, Neuner M, et al. Intraventricular meningiomas: a report of 16 cases. Neurosurg Rev. 2006;29:30-5.

19. Castillo RG, Geise AW. Meningioma of the third ventricle. Surg Neurol. 1985;24(5):525-8. doi: 10.1016/0090-3019(85) 90268-x.

20. Guidetti B, Delfini R, Gagliardi FM, Vagnozzi R. Meningiomas of the lateral ventricles. Clinical, neuroradiologic, and surgical considerations in 19 cases. Surg Neurol. 1985;24(4): 364-70. doi: 10.1016/0090-3019(85)90292-7.

21. Qin Y, Kanasaki Y, Takasugi M, Shinohara Y, Kaminou T, Kurosaki $\mathrm{M}$, et al. Primary fourth ventricular meningioma: a case report of an adult male. Clin Imaging. 2012;36(4):379-82. doi: 10.1016/j.clinimag.2011.11.034.

22. Cushing H, Eisenhardt L. Meningiomas. Their Classification, Regional Behavior, Life History and Surgical End Results. Springfield, IL: Charles C Thomas, 1938; pp 139-49.

23. Fu Z, Xu K, Xu B, Qu L, Yu J. Lateral ventricular meningioma presenting with intraventricular hemorrhage: a case report and literature review. Int J Med Sci. 2011;8(8):711-6. doi: 10.7150/ ijms.8.711.

24. Romeike BFM, Joellenbeck B, Skalej M, Scherlach C, Kirches $\mathrm{E}, \mathrm{Mawrin} \mathrm{C}$. Intraventricular meningioma with fatal haemorrhage: clinical and autopsy findings. Clin Neurol Neurosurg. 2007;109(10):884-7. doi: 10.1016/j.clineuro.2007.07.016.

25. Louis DN, Perry A, Reifenberger G, von Deimling A, Figarella-Branger D, Cavenee WK, et al. The 2016 World Health Organization Classification of Tumors of the Central Nervous System: a summary. Acta Neuropathol. 2016;131(6):803-20. doi: 10.1007/s00401-016-1545-1.

26. Shaw A. Fibrous tumour in the lateral ventricle of the brain, boney deposits in the arachnoid membrane of the right hemisphere. Trans Path Soc Lond. 1854;5:18-21.

27. McDermott MW. Intraventricular meningiomas. Neurosurg Clin North Am. 2003;14:559-69.

28. Fornari M, Savoiardo M, Morrello G, Solero CL. Meningiomas of the lateral ventricles. Neuroradiological and surgical considerations in 18 cases. J Neurosurg. 1981;54:64-74. doi: 10.3171/jns.1981.54.1.0064.

29. Zanini MA, Faleiros AT, Almeida CR, Clara CA, Gabarra RC. Trigone ventricular meningiomas: surgical approaches. Arq Neuropsiquiatr. 2011;69(4):670-5. doi: 10.1590/s0004-282x20 11000500018.

30. Menon G, Nair S, Sudhir J, Rao R, Easwer HV, Krishnakumar $\mathrm{K}$. Meningiomas of the lateral ventricle - a report of 15 cases. Br J Neurosurg. 2009;23:297-303. doi: 10.1080/026886909 02721862.

Sažetak

\section{MIKROKIRURŠKO LIJEČENJE RIJETKOG SLUČAJNO NAĐENOG INTRAVENTRIKULSKOG MENINGEOMA: PRIKAZ SLUČAJA I PREGLED RELEVANTNE LITERATURE}

\section{Raguž, A. Rotim, T. Sajko, M. Jurilj, B. Splavski i K. Rotim}

Intraventrikulski meningeomi su vrlo rijetki, čineći između $0,5 \%$ i 3\% svih intrakranijskih meningeoma te zbog svoga zahtjevnog položaja predstavljaju najizazovnije tumore za kirurško liječenje. Kako su početno asimptomatski, ovakvi tumori često ostaju dugo klinički i radiološki neprepoznati prije no što dosegnu kritičnu veličinu. Dostupna literatura o načinima njihovog kirurškog liječenja je još uvijek oskudna. U ovom radu predstavljamo mikrokirurško uklanjanje slučajno nađenog intraventrikulskog meningeoma kroz prikaz slučaja žene u dobi od 32 godine koja je primljena u bolnicu zbog naglog gubitka svijesti, retrogradne amnezije i povraćanja nastalih kao posljedica pretrpljene ozljede glave. Rutinska magnetna rezonancija mozga otkrila je nepravilnu ekspanzivnu tvorbu smještenu unutar zatiljnog roga desne postranične moždane klijetke koja se raznovrsno obojala nakon primjene kontrastnog sredstva. Temeljem ovoga nalaza u bolesnice je učinjena desnostrana temporalna osteoplastička kraniotomija i tumor je mikrokirurški uklonjen u cijelosti, nakon čega je postavljena izvanjska ventrikulska drenaža te je uslijedio potpun oporavak. Patohistološka analiza uzoraka tumorskog tkiva potvrdila je tumor kao meningeom I. stupnja prema klasifikaciji Svjetske zdravstvene organizacije. Poslijeoperacijska kompjutorizirana tomografija mozga potvrdila je potpunu tumorsku resekciju. U zaključku, intraventrikulski meningeomi su prilično rijetki ekstra-aksijalni tumori koji se očituju različitim simptomima ovisnima o njihovoj veličini i zahtjevnom položaju. Zahvaljujući razvitku najsuvremenijih metoda radiološkog oslikavanja znatno je poboljšana mogućnost njihove primjerene i točne dijagnostike, boljeg planiranja kirurškog zahvata i poboljšanog ishoda liječenja. Potpuno mikrokirurško uklanjanje tumora, uz pomoć intraoperacijskog neurofiziološkog praćenja i uporabu najsuvremenijeg neurokirurškog instrumentarija, najbolja je metoda izbora u liječenju ovih lokacijski i kirurški vrlo zahtjevnih, pretežito dobroćudnih intrakranijskih tumora.

Ključne riječi: Meningeom, intraventrikulski, slučajni; Mikrokirurško liječenje 